\title{
Actual and predicted prevalence of alcohol consumption during pregnancy in Latin America and the Caribbean: systematic literature review and meta-analysis
}

\author{
Shannon Lange, ${ }^{1}$ Charlotte Probst, ${ }^{1}$ Navrose Heer, ${ }^{1}$ Michael Roerecke, ${ }^{1}$ Jürgen \\ Rehm, ${ }^{1}$ Maristela G. Monteiro, ${ }^{2}$ Kevin Shield, ${ }^{1}$ Claire de Oliveira, ${ }^{1}$ and \\ Svetlana Popova ${ }^{1}$
}

Suggested citation Lange S, Probst C, Heer N, Roerecke M, Rehm J, Monteiro MG, et al. Actual and predicted prevalence of alcohol consumption during pregnancy in Latin America and the Caribbean: systematic literature review and meta-analysis. Rev Panam Salud Publica. 2017;41:e89.

ABSTRACT Objective. To estimate the prevalence of alcohol consumption during pregnancy among the general population of Latin America and the Caribbean, by country, in 2012.

Methods. Three steps were taken: a comprehensive, systematic literature search; meta-analyses, assuming a random-effects model for countries with published studies; and regression modelling (data prediction) for countries with either no published studies or too few to obtain an estimate.

Results. Based on 24 existing studies, the pooled prevalence of alcohol consumption during pregnancy among the general population was estimated for Brazil (15.2\%; 95\% confidence interval [95\%CI]: 10.4\%-20.8\%) and Mexico (1.2\%; 95\% CI: 0.0\%-2.7\%). The prevalence of alcohol consumption during pregnancy among the general population was predicted for 31 countries and ranged from 4.8\% (95\%CI: 4.2\%-5.4\%) in Cuba to $23.3 \%$ (95\% CI: $20.1 \%-$ $26.5 \%$ ) in Grenada.

Conclusions. Greater prevention efforts and measures are needed in the countries of Latin America and the Caribbean to prevent pregnant women from consuming alcohol during pregnancy and decrease the rates of Fetal Alcohol Spectrum Disorder. Additional high quality studies on the prevalence of alcohol consumption during pregnancy in Latin America and the Caribbean are also needed.

Keywords Alcohol drinking; pregnancy; prenatal care; fetal development; Latin America; Caribbean Region.

Research on alcohol consumption among women in the Region of the Americas has primarily focused on Canada and the United States of America, and less on Central and South America and the Caribbean. Nevertheless, alcohol consumption among women in these areas remains problematically high compared to the world

\footnotetext{
Institute for Mental Health Policy Research, Center for Addiction and Mental Health, Toronto, Ontario, Canada. Send correspondence to Svetlana Popova, lana.popova@camh.ca

2 Pan American Health Organization, Washington DC, United States of America.
}

average. According to the Global Status Report on Alcohol and Health (1), in 2010 the highest per capita consumption of pure alcohol among women (defined as $15+$ years of age) in Central America was in Panama (4.7L), Costa Rica (3.2L), and Mexico (2.6L); in South America, Chile (5.5L), Argentina (5.2L), and Paraguay (5.2L); and in the Caribbean, Grenada (7.3L), Saint Lucia (5.9L), and Saint Kitts and Nevis (4.7L). Notably, in the same year, women in most of the countries $(78 \%)$ in Latin America and the Caribbean (LAC) had higher pure alcohol per capita consumption (APC) than the global average APC for women (2.7L) (1). Furthermore, in 2010 the highest prevalence rates of heavy episodic drinking $(\geq 60 \mathrm{~mL}$ of pure alcohol on at least one occasion monthly) among women in Central America were in Guatemala (14.2\%), El Salvador $(13.6 \%)$, and Nicaragua (6.6\%); in South America, Paraguay (41.0\%), Venezuela $(21.8 \%)$, and Brazil (11.1\%); and in the Caribbean, Saint Kitts and Nevis $(33.1 \%)$, Dominica $(29.6 \%)$, and Trinidad and Tobago (24.4\%) (1). The majority of these figures are significantly higher than the global prevalence of 
heavy episodic drinking among women drinkers, which was 5.7\% in 2010 (1).

These data demonstrate that not only are women in LAC drinking at high rates, but many of them are engaging in risky drinking patterns. As such, it is likely that some women may continue to drink during pregnancy or before becoming aware of a pregnancy. Furthermore, a recent study found LAC to have the highest proportion of unintended pregnancies (56\%), while other regions, i.e., Africa, Asia, Europe, North America, and Oceania, ranged from $35 \%$ to $51 \%$; the worldwide average being $40 \%$ (2). Coupled with the relatively high rates of alcohol consumption and risky drinking patterns, this may lead to an increased risk of alcohol-exposed pregnancies in these countries.

It is a well-known fact that alcohol is a teratogen that can cause significant harm to a developing fetus. Worldwide, the majority of clinical guidelines advocate that women who are pregnant or planning to become pregnant should abstain from alcohol due to potential adverse health consequences, which could include spontaneous abortion, stillbirth, intrauterine growth retardation, low birth weight, preterm labor, birth defects, and Fetal Alcohol Spectrum Disorder (FASD) (3-8). FASD encompasses a broad array of physical defects and cognitive, behavioral, emotional, and adaptive functioning deficits, as well as congenital anomalies. The effects of alcohol on the fetus are permanent, and as such, many people with FASD require lifelong support, resulting in a significant cost to society $(9,10)$.

There is a general paucity of research on the prevalence of FASD in LAC countries. Few studies have reported the prevalence of Fetal Alcohol Syndrome (FAS; the most severe and visibly identifiable form of FASD) in South America. Specifically, it has been reported to be $0.1 \%$ among the general population of Brazil and Uruguay $(11,12)$. However, the prevalence of FAS and partial FAS among children in care in Chile has been reported to be much higher: $15 \%$ among those in foster homes (13), and 16\% among those in child welfare custody and homes for those with mental deficiencies (14). A study of 103 children living in the United States who were adopted from Guatemala found that $28 \%$ had the phenotypic facial features suggestive of prenatal alcohol exposure (15).

The objective of the current study was to estimate the prevalence of alcohol consumption (any amount) during pregnancy among the general population of LAC.

\section{MATERIALS AND METHODS}

In order to estimate the prevalence of alcohol consumption (any amount) during pregnancy among the general population of $\mathrm{LAC}^{3}$ three steps were taken: (i) a comprehensive systematic literature search; (ii) meta-analyses based on the existing studies; and (iii) regression modelling (data prediction) for countries with either no published studies or too few to obtain an estimate.

\section{Comprehensive systematic literature search}

Search strategy. A comprehensive systematic literature review was conducted and reported according to the standards set out in Preferred Reporting Items for Systematic Reviews and Meta-Analyses (16), and guided by the overview of Egger and colleagues (17). The search was performed to identify studies published in January 1984 - June 2014, i.e., in the last 30 years, without language restriction. The search was conducted in multiple electronic bibliographic databases: MEDLINE, PubMed, EMBASE, Web of Science (including Science Citation Index, Social Sciences Citation Index, Arts and Humanities Citation Index), PsycINFO, ERIC, Ebscohost, CINAHL, Campbell Collaboration, the Cochrane Database of Systematic Reviews, CSA Sociological Abstracts, Social Work Abstracts, Canadian Centre on Substance Abuse Library Collection Database, National Institute on Alcohol Abuse and Alcoholism's Alcohol and Alcohol Problems Science Database (ETOH), Scopus, Centre for Addiction and Mental Health Library Database, and Google Scholar. Multiple combinations of the following keywords were used: alcohol, binge, ethanol;

\footnotetext{
Central America: Belize, Costa Rica, El Salvador, Guatemala, Honduras, Mexico, Nicaragua, and Panama; South America: Argentina, Bolivia, Brazil, Chile, Colombia, Ecuador, Guyana, Paraguay, Peru, Suriname, Uruguay, and Venezuela; and the Caribbean: Antigua and Barbuda, Bahamas, Barbados, Cuba, Dominica, Dominican Republic, Grenada, Haiti, Jamaica, Saint Kitts and Nevis, Saint Lucia, Saint Vincent and the Grenadines, and Trinidad and Tobago.
}

behavi*, consum*, drink* ${ }^{*}$, maternal, mother, primigravida, wom*n; pregnant, pregnanc*, prenatal; epidemiology, frequenc*, occurrence, prevalence; and Antigua and Barbuda, Argentina, Bahamas, Barbados, Belize, Bolivia, Brazil, Caribbean, Central America, Chile, Colombia, Costa Rica, Cuba, Dominica, Dominican Republic, Ecuador, El Salvador, Grenada, Guatemala, Guyana, Haiti, Honduras, Jamaica, Latin America, Mexico, Nicaragua, Panama, Paraguay, Peru, Saint Kitts and Nevis, Saint Lucia, Saint Vincent and the Grenadines, South America, Suriname, Trinidad and Tobago, Uruguay, and Venezuela. In addition, the content pages of the major epidemiological journals, as well as citations in the relevant articles, were manually screened.

Study selection. Study selection began by screening the titles and abstracts of studies for inclusion. Then, full-text articles of all studies screened as potentially relevant were considered. The following inclusion criteria were then applied to determine eligibility: (i) consisted of original quantitative research published in a peer-reviewed journal or scholarly report (i.e., a report written by scholars/professionals who are experts in the field of alcohol use during pregnancy and published on an institutional/government website); and (ii) measured the prevalence of alcohol consumption during pregnancy among the general population in any country in Latin America or the Caribbean. Articles were excluded if they (i) excluded abstainers from their samples (which would lead to an inflated estimate), or (ii) reported a pooled estimate of alcohol use during pregnancy by combining several studies. Regarding the latter exclusion criterion, the primary studies were included. Two investigators conducted each study selection step independently; any disagreements were reconciled by team discussion. In cases where multiple studies used the same dataset or cohort, the study with the larger sample size was included.

Data extraction. All data were extracted by one investigator, and then independently crosschecked by a second investigator for accuracy against the original studies. The following variables were extracted: country; study year(s); timing of data collection; sample size; setting; sociodemographic status, i.e., 
income, education, occupation/employment status, marital status; instrument used to obtain alcohol use data; percentage of women who consumed alcohol, binge drank, used drugs, and/or smoked during pregnancy; as well as the number of previous pregnancies, number of previous live births, and percentage of unplanned pregnancies (for the index pregnancy). Using a checklist for observational studies developed a priori based on the criteria described and validated in Wong and colleagues (18), two investigators independently appraised the quality of each study. The following criteria were used: (i) representativeness of the sample (i.e., used probability or non-probability sampling); (ii) adequate sample size ( $\geq 300$ participants); (iii) utilization of a validated tool to ascertain alcohol use during pregnancy, e.g., the Alcohol Use Disorders Identification Test-Consumption (AUDIT-C; 19), CRAFFT screening interview (20), and 4P's Plus screen (21); (iv) adequate response/participation rate $(\geq 60 \%)$, and (v) whether or not the study subjects were described. All discrepancies in quality ratings were reconciled by team discussion. Inter-rater agreement for inclusion and quality assessment was assessed using Fleiss's kappa statistics (22). Training of coders to achieve sufficient $(>0.80)$ inter-rater reliability was conducted.

\section{Meta-analyses}

A meta-analysis was performed for each country where at least three estimates of the prevalence of alcohol consumption during pregnancy were available. The criterion of three estimates was chosen in order to reduce the chance of presenting biased estimates that were not generalizable. In cases where a study reported the prevalence of alcohol consumption during pregnancy by (i) the time at which alcohol consumption was measured, or (ii) the trimester of alcohol consumption, (iii) awareness of pregnancy (i.e., before and after pregnancy recognition), or by (iv) method of ascertainment (e.g., medical chart and questionnaire), preference was given to studies that: (i) assessed alcohol consumption soon after delivery (within 6 weeks postpartum), (ii) reported the prevalence of alcohol consumption during the course of the entire pregnancy (as opposed to just in the first trimester, for example), (iii) assessed alcohol consumption after pregnancy recognition, and (iv) used a validated tool for ascertainment of alcohol consumption.

The prevalence estimates underwent a double arcsine transformation so that the data followed a normal distribution, an assumption needed when statistically combining estimates (23). In each case, in order to combine prevalence estimates, the meta-analysis was conducted using a random-effects model (24). Heterogeneity between double arcsine-transformed estimates of drinking during pregnancy was assessed using the $\mathrm{I}^{2}$ statistic (25). Publication bias was examined by visually inspecting the funnel plot (standard error plotted against the point estimate) for a skewed distribution and by employing Egger's regression test for smallstudy effects (26).

\section{Data prediction}

For the countries with either no published data or fewer than three published studies on the topic, prevalence estimates were predicted using prevalence data of more than 300 studies from 50 countries (i.e., data were not limited to the Americas; 27). A fractional response regression model was employed to restrict predictions to values between 0 and 1 (28). Country- and year-specific explanatory variables were gross domestic product (adjusted for purchasing power parity) per capita (29), mean total consumption of alcohol among women (1), and the WHO Region within which the country was located. If study year(s) was not reported, the year of publication was used. If the study was conducted across 2 or more years, a value for each of the explanatory variables was calculated as the average of the value from the study's start year to that of its end year. Total mean alcohol consumption among women was estimated as the proportion of the total amount of alcohol consumed in the respective country that was consumed by women in 2010/2012 (1). In order to account for the heterogeneity within the Region of the Americas and the European Region, particularly with respect to income level and drinking culture, these regions were divided by income level (for Europe: countries that belong to the European Union versus countries that do not; and for the Americas: Canada and the United States versus the remaining countries).

Predictions were based on the values of the above named explanatory variables for the year 2012. In order to be conservative, the confidence interval (CI) for each estimate was based on the standard deviation of the prediction. All statistics were performed using $\mathrm{R}$ version 3.1.0 (R Development Core Team, Vienna, Austria).

\section{RESULTS}

\section{Comprehensive systematic literature search}

Initially, the search yielded a total of 956 publications for LAC countries; 954 articles identified through the electronic search, and two through the manual search. After removing 542 duplicate articles, the remaining 414 articles were screened using titles and abstracts. The full-texts of 87 articles were retrieved for further consideration, 63 of which were subsequently excluded. A total of 24 articles (all from peer-reviewed journals) contained relevant data and were retained for data extraction. Inter-rater agreement for inclusion and quality assessment was excellent $(\kappa=0.96$ and $\kappa=0.93$, respectively). Data from published studies on the prevalence of alcohol consumption during pregnancy were available from 5 of the 33 countries in LAC (Brazil, $n=17$ (30-46); Chile, $n=2$ (47, 48); Guatemala, $n=1$ (49); Mexico, $n=3$ (50-52); and Uruguay, $n=1$ (53); there were no studies of the Caribbean).

All of the included studies presented data on self-reported alcohol consumption during pregnancy. The characteristics of the participants (e.g., sociodemographic characteristics) in each study are available from the authors upon request.

In regard to study quality, $88 \%$ used non-probability sampling and only 13\% utilized a validated tool to ascertain alcohol use. However, $96 \%$ of the studies described their study participants, $92 \%$ had an adequate sample size, and $54 \%$ had a reasonable participation rate (quality ratings of the included studies are available from the authors upon request).

\section{Prevalence reported by individual studies}

Overall, the prevalence of alcohol consumption during pregnancy among the general population in the 24 identified studies ranged from $0.4 \%$ in Mexico (50) to $57.4 \%$ in Chile (47; Table 1). Only three studies reported the prevalence of 


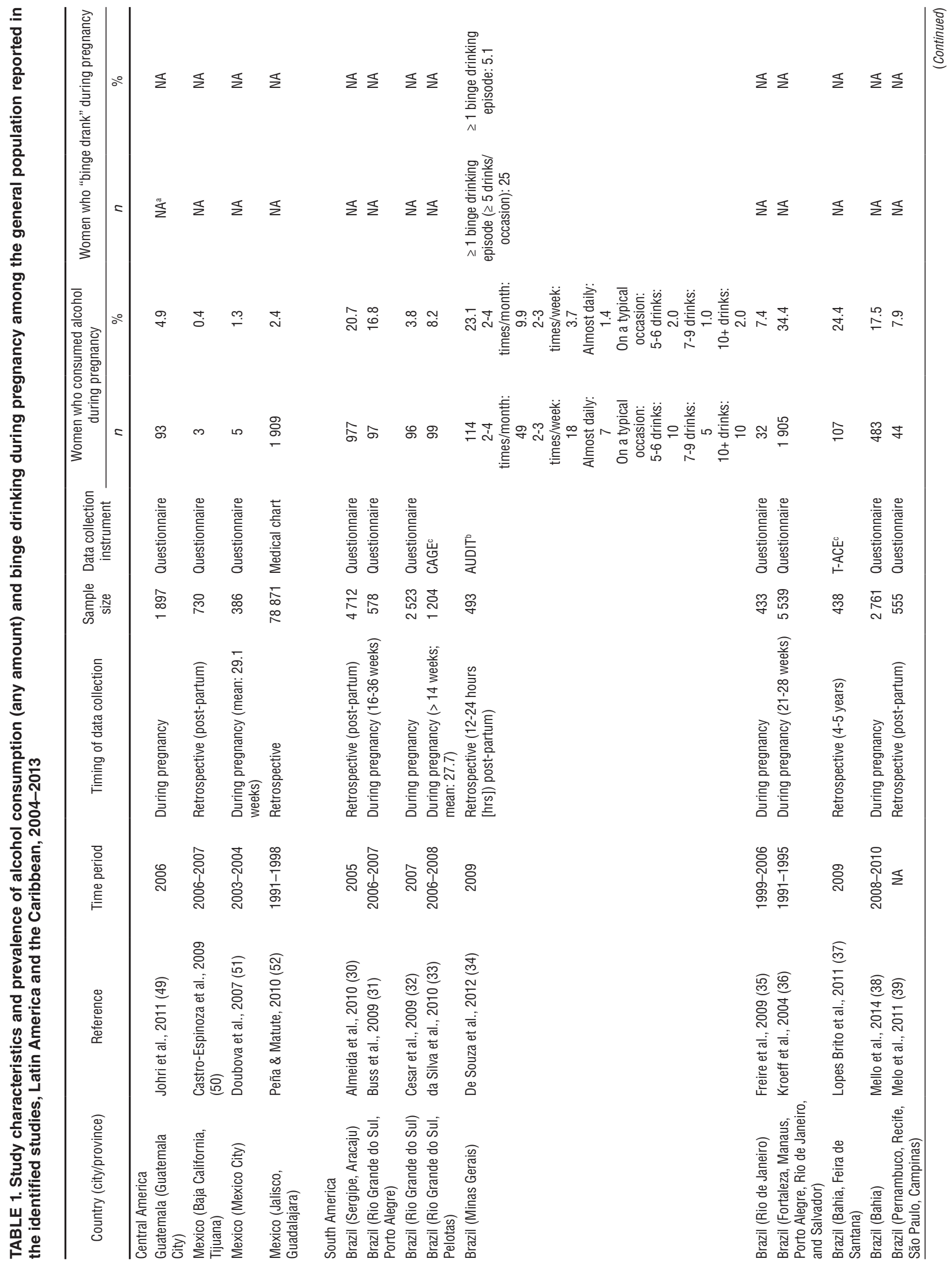




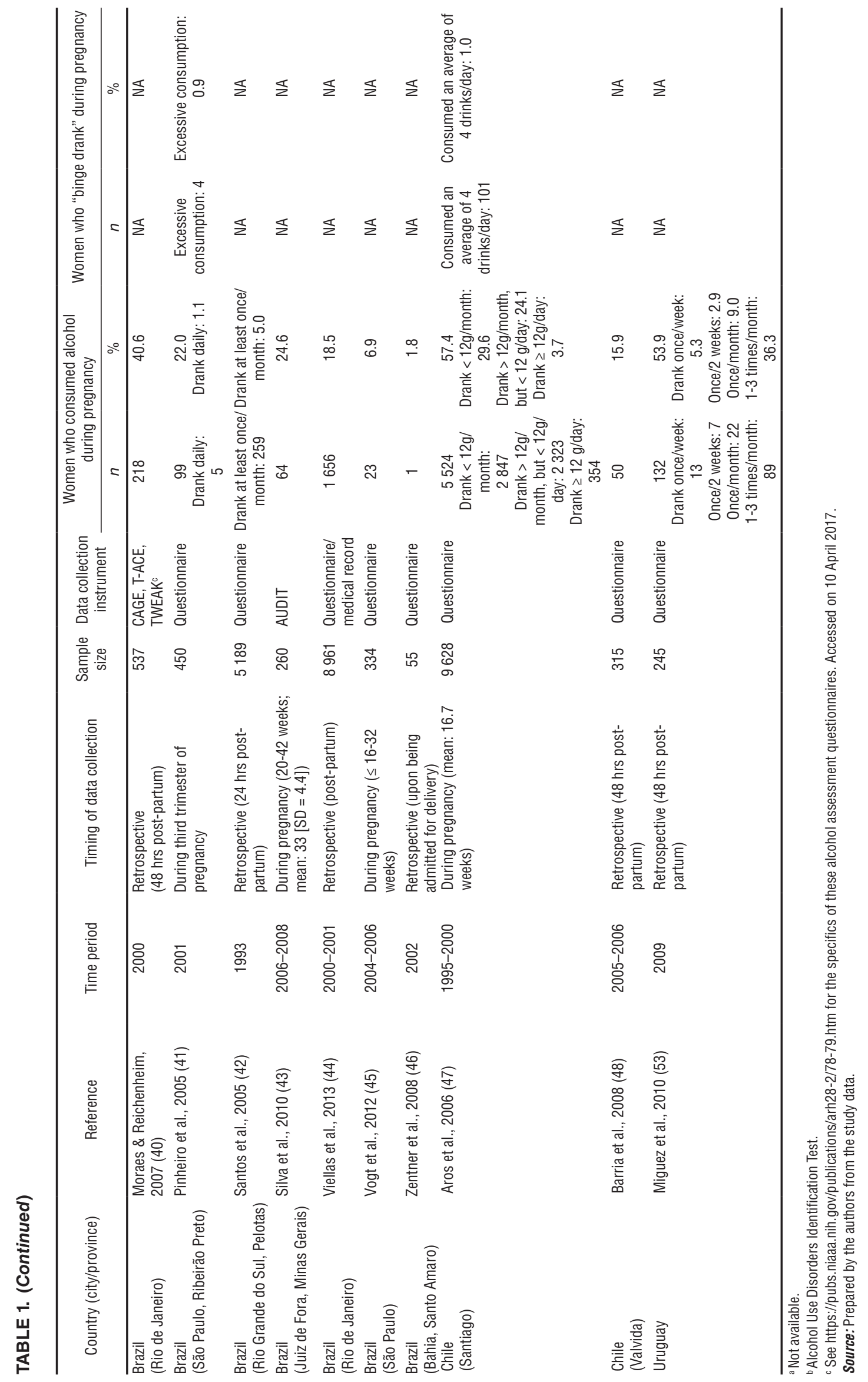


binge/excessive drinking of women during pregnancy in the general population: $5.1 \%$ binge drank ( $\geq 5$ drinks on a single occasion) in Brazil (34), 0.9\% had "excessive consumption" (not further defined) in Brazil (41), and $1.0 \%$ consumed an average of four drinks per drinking day in Chile (47).

\section{Meta-analyses}

It was only possible to conduct a meta-analysis for Brazil and Mexico, based on the criterion of three available studies per country. The pooled prevalence of alcohol consumption during pregnancy among the general population in Brazil was estimated to be $15.2 \%$ (95\%CI: $10.4 \%-20.8 \%$ ), and contained estimates ranging from $1.8 \%$ (46) to $40.6 \%$ (40; Figure 1).

The pooled prevalence of alcohol consumption during pregnancy among the general population in Mexico was estimated to be $1.2 \%(95 \%$ CI: $0.0 \%-2.7 \%)$,

FIGURE 1. Forest plot of the prevalence estimates of alcohol consumption (any amount) during pregnancy among the general population of Brazil, 2004-2013

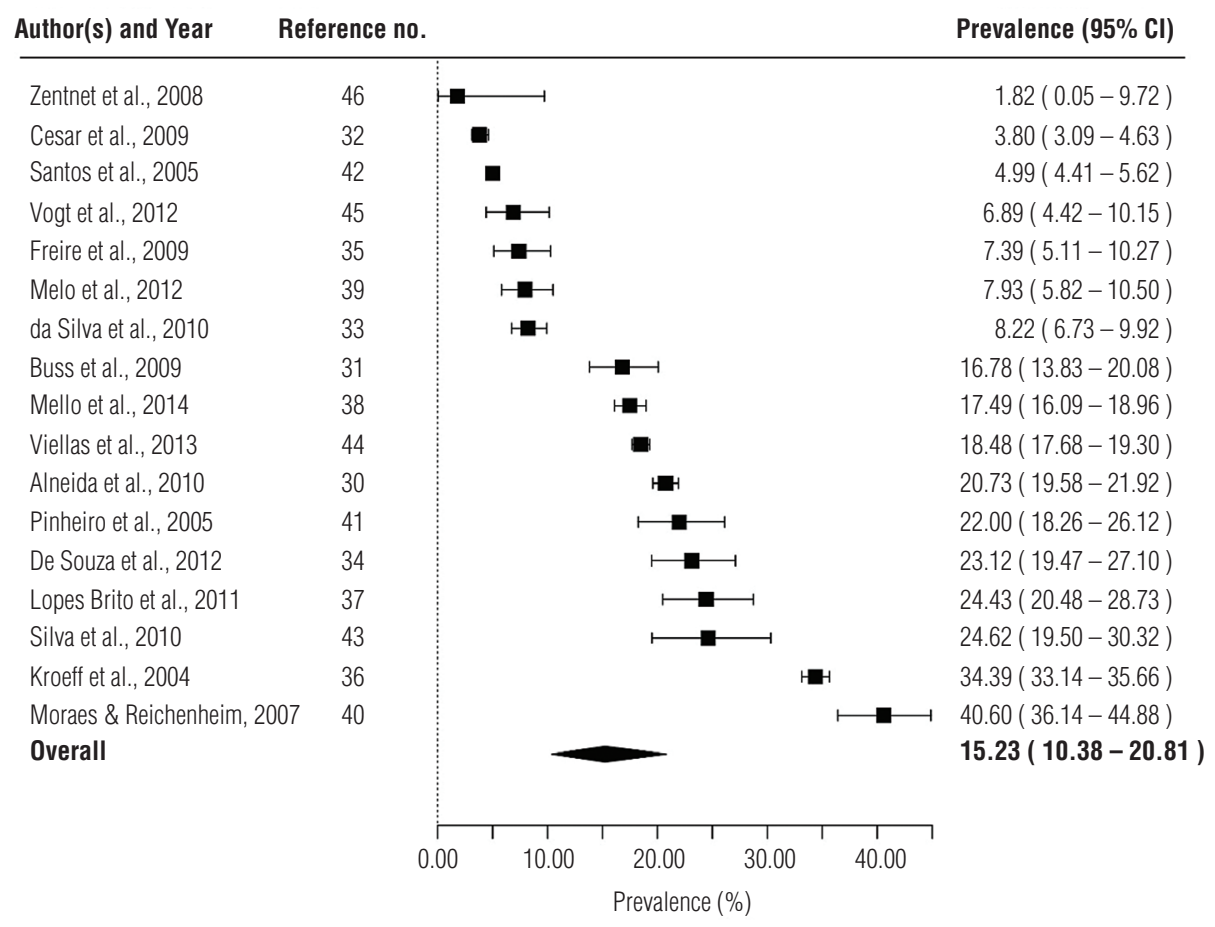

and contained estimates ranging from $0.4 \%$ (50) to $2.4 \%$ (52; Figure 2).

The tests of heterogeneity demonstrated that heterogeneity was present in the estimates of alcohol consumption during pregnancy $\left(\mathrm{I}^{2}=99.4 \%\right.$ for Brazil and $\mathrm{I}^{2}=89.1 \%$ for Mexico). We did not find evidence for the presence of publication bias in these meta-analyses $(P=0.326$ for Brazil and $P=0.370$ for Mexico).

\section{Data prediction}

The prevalence of alcohol consumption during pregnancy was predicted for 31 countries with either no published data or fewer than three studies available. The three countries with the highest predicted prevalence of alcohol consumption during pregnancy among the general population were Grenada $(23.3 \%$, 95\%CI: $20.1 \%-26.5 \%)$, St. Lucia $(21.8 \%$, 95\%CI: $19.0 \%-24.7 \%)$, and Guyana (18.2\%, 95\%CI: $16.1 \%-20.2 \%$; Table 2). The three countries with the lowest predicted prevalence of alcohol consumption during pregnancy among the general population were Cuba $(4.8 \%$, 95\%CI: $4.2 \%-5.4 \%)$, Trinidad and Tobago (5.6\%, 95\%CI: $4.8 \%-$ $6.5 \%)$, and Guatemala $(6.5 \%, 95 \% \mathrm{CI}$ : $5.6 \%-7.4 \%$; Table 2).

The prevalence of alcohol consumption during pregnancy among the general population appears to be the highest in countries of the Caribbean and South America- $61.5 \%$ of Caribbean countries and $75.0 \%$ of South American countries had a prevalence greater than or equal to $10 \%$, compared to $25.0 \%$ in Central America (Figure 3).

FIGURE 2. Forest plot of the prevalence estimates of alcohol consumption (any amount) during pregnancy among the general population of Mexico, 2007, 2009, 2010

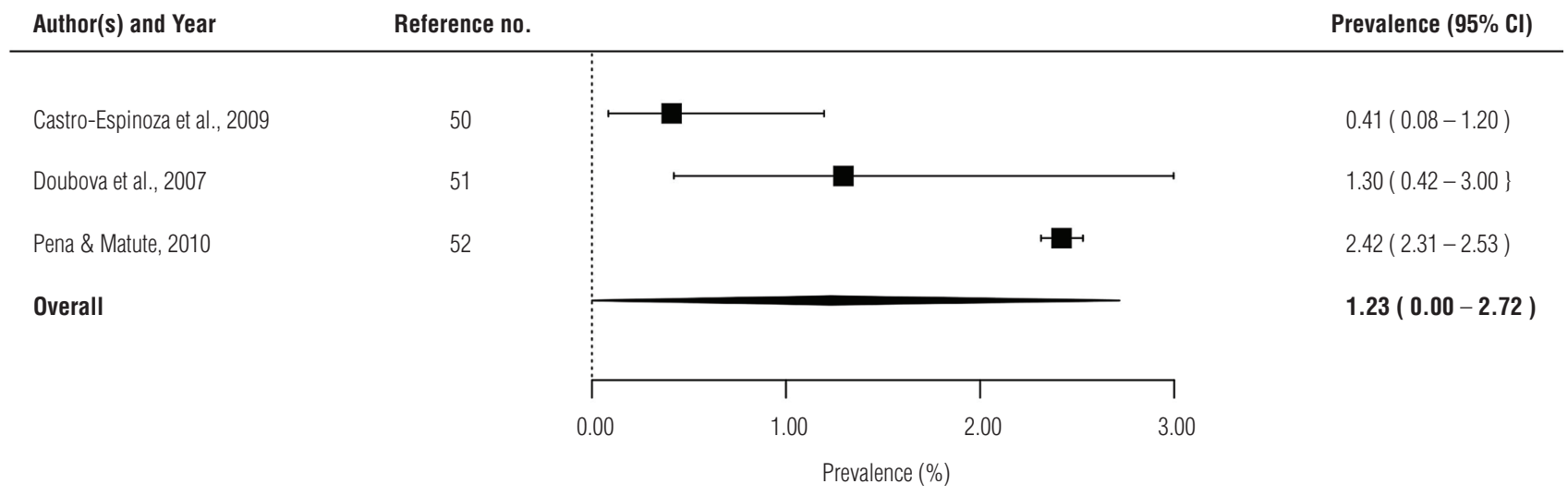

Source: Prepared by the authors from the study data. 
TABLE 2. The prevalence of alcohol consumption (any amount) during pregnancy among the general population of Latin America and the Caribbean, by country, 2012

\begin{tabular}{|c|c|c|c|}
\hline \multirow{2}{*}{ Country } & \multirow{2}{*}{ Estimate (\%) } & \multicolumn{2}{|c|}{ 95\% Confidence Interval } \\
\hline & & Lower (\%) & Upper (\%) \\
\hline \multicolumn{4}{|l|}{ Caribbean } \\
\hline Antigua and Barbuda & 9.7 & 8.3 & 11.0 \\
\hline Bahamas & 12.0 & 10.1 & 14.0 \\
\hline Barbados & 14.7 & 12.7 & 16.7 \\
\hline Cuba & 4.8 & 4.2 & 5.4 \\
\hline Dominica & 14.6 & 12.9 & 16.3 \\
\hline Dominican Republic & 12.1 & 10.7 & 13.5 \\
\hline Grenada & 23.3 & 20.1 & 26.5 \\
\hline Haiti & 14.9 & 13.3 & 16.6 \\
\hline Jamaica & 9.4 & 8.3 & 10.5 \\
\hline St. Kitts and Nevis & 9.5 & 8.2 & 10.8 \\
\hline St. Lucia & 21.8 & 19.0 & 24.7 \\
\hline St. Vincent and Grenadines & 14.9 & 13.2 & 16.7 \\
\hline Trinidad and Tobago & 5.6 & 4.8 & 6.5 \\
\hline \multicolumn{4}{|l|}{ Central America } \\
\hline Belize & 9.6 & 8.4 & 10.7 \\
\hline Costa Rica & 8.3 & 7.3 & 9.3 \\
\hline El Salvador & 8.3 & 7.3 & 9.3 \\
\hline Guatemala & 6.5 & 5.6 & 7.4 \\
\hline Honduras & 10.6 & 9.4 & 11.9 \\
\hline Mexico $^{\mathrm{a}}$ & 1.2 & 0.0 & 2.7 \\
\hline Nicaragua & 8.9 & 7.8 & 10.0 \\
\hline Panama & 11.7 & 10.1 & 13.2 \\
\hline \multicolumn{4}{|l|}{ South America } \\
\hline Argentina & 12.9 & 11.1 & 14.7 \\
\hline Bolivia & 10.5 & 9.3 & 11.7 \\
\hline Brazila & 15.2 & 10.4 & 20.8 \\
\hline Chile & 10.6 & 9.1 & 12.2 \\
\hline Colombia & 9.1 & 8.0 & 10.1 \\
\hline Ecuador & 8.9 & 7.8 & 9.9 \\
\hline Guyana & 18.2 & 16.1 & 20.2 \\
\hline Paraguay & 17.9 & 15.9 & 20.0 \\
\hline Peru & 12.5 & 11.0 & 13.9 \\
\hline Suriname & 10.2 & 8.9 & 11.4 \\
\hline Uruguay & 8.8 & 7.6 & 9.9 \\
\hline Venezuela & 10.0 & 8.7 & 11.2 \\
\hline
\end{tabular}

${ }^{a}$ Estimate based on a meta-analysis of the current literature.

Source: Prepared by the authors from the study data.

\section{DISCUSSION}

The prevalence of alcohol consumption during pregnancy among the general population of the Caribbean ranged from $4.8 \%$ in Cuba to $23.3 \%$ in Grenada; in Central America, from $1.2 \%$ in Mexico to $11.7 \%$ in Panama; and in South America, from 8.8\% in Uruguay to $18.2 \%$ in Guyana. Overall, our findings show a relatively high prevalence of alcohol consumption during pregnancy among the general population in some LAC countries, with 18 countries having an estimated prevalence of greater than or equal to $10 \%$. Although some LAC the top 10 wine-producing countries in the world, and several other South American countries have impressive beer-production industries, including Brazil, which ranks among the top five worldwide (60).

However, some of the identified studies report an unrealistically high prevalence of alcohol consumption during pregnancy among the general population. For example, the prevalence reported for Chile $(57.4 \% ; 47)$ and Uruguay $(53.9 \%$; 53) are notably higher than the estimates predicted for these countries (10.6\%; 95\%CI: 9.1\%$12.2 \%$, and $8.8 \%$; $95 \% \mathrm{CI}: 7.6 \%-9.9 \%$, respectively). These reported prevalence rates also approach, and in the case of Uruguay exceed, the prevalence of current female drinkers (15+ years of age) among the general population in these countries (approximately $59 \%$ in Chile and $48 \%$ in Uruguay; 61). As such, the predicted prevalence of alcohol consumption during pregnancy is much more realistic for those countries with fewer than three available studies.

Furthermore, a recently published study from Argentina reported an alarmingly high prevalence, with $75 \%$ of women in the general population consuming at least one drink $(10 \mathrm{~mL}-12 \mathrm{~mL})$ of alcohol during their pregnancy (62). However, according to Pan American Health Organization, only $48 \%$ of females in the general population of Argentina currently consume alcohol (61). Therefore, the predicted prevalence for Argentina (12.9\%; 95\%CI: $11.1 \%-14.7 \%$ ) is more reasonable. Similarly, a study utilizing meconium testing in Montevideo, Uruguay, reported that $43.5 \%$ of samples tested positive for fatty acid ethyl esters above standard cut-off levels (i.e., $2 \mathrm{n} \mathrm{mol} / \mathrm{g}$ ) among women from lowand mid-to-low socioeconomic levels (63).

The comprehensive search strategy, a priori inclusion and exclusion criteria, and statistical analysis are notable strengths of the current study. Additionally, studies with sample composed of participants with low socioeconomic status or high-risk behaviors (e.g., all smokers) were excluded from the current study; thus, the generalizability of the findings to the general population is strengthened.

\section{Limitations}

A few limitations should be noted. First, the majority of studies included in the current analysis utilized non-probability sampling and did not use validated tools to ascertain alcohol consumption during 
FIGURE 3. Prevalence of alcohol consumption during pregnancy among the general population of Latin America and the Caribbean, based on the two methods (meta-analyses versus weighted regression modelling/data prediction), 2012

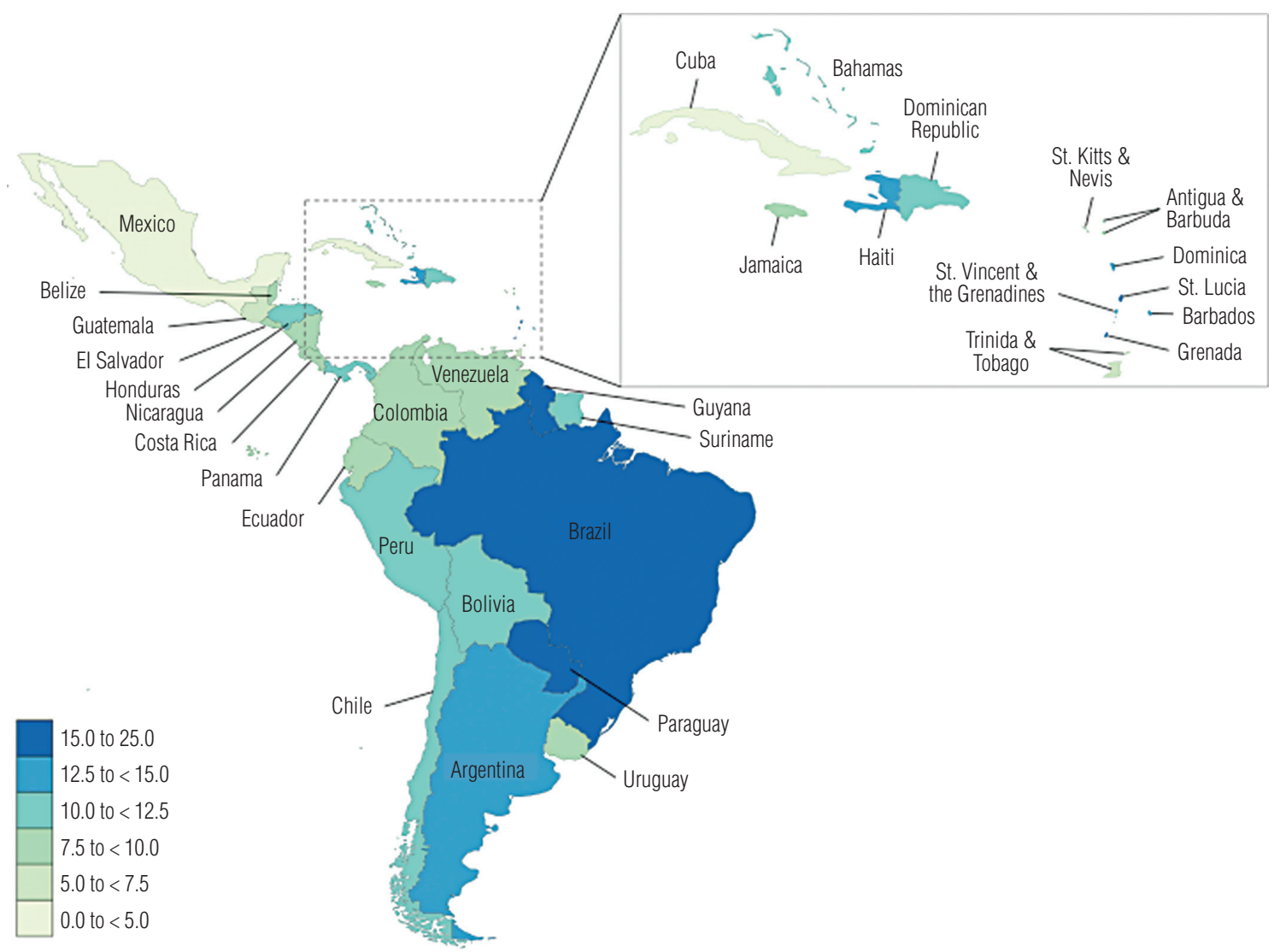

Note: Prediction of the prevalence of alcohol consumption during pregnancy for Argentina was not possible due to missing data. Source: Prepared by the authors from the study data.

pregnancy. However, recent research shows that non-probability sampling techniques (e.g., convenience sampling) can be a suitable sampling strategy when exploring exposures during pregnancy (64). Also, it has been shown that a single question can detect as many (if not more) women who drink as other commonly used prenatal screens (65). Second, data on alcohol consumption during pregnancy were obtained through self-reported measures; therefore, reporting and recall biases may be present. As such, the prevalence of alcohol consumption during pregnancy may be underestimated in the current study. Third, the predicted prevalence values may differ from the true prevalence for a few reasons, namely: (i) data from which the values are predicted are not flawless, (ii) there may be other factors influencing the prevalence (e.g., different health and alcohol policies in different countries) that were not possible to take into account in the prediction model, and (iii) the ecological predictors may not allow for a precise estimate of the prevalence of alcohol consumption during pregnancy in the respective country. Despite these limitations, this study used the best available data and provides a working estimate of the prevalence of alcohol consumption during pregnancy in countries of LAC that do not currently have actual data. When data becomes available, further research can refine these estimates over time.

\section{Conclusions}

Data on the prevalence of alcohol consumption during pregnancy in countries of Latin America are scarce, and in the Caribbean, are completely absent. As such, there is an urgent need for high quality studies to be conducted in countries of LAC. Regardless, this study's findings point to the fact that measures are needed to deter pregnant women from consuming alcohol, and thus, reduce the occurrence of prenatal alcohol exposure and FASD. As prevention is key, educating women of childbearing age about the potential adverse consequences is of utmost importance.
When an infant with FASD is born, it is imperative that the mother receive substance abuse treatment. Treatment will reduce the chances of subsequent children with FASD, and increase the likelihood that the affected child and mother will be routinely monitored. Therefore, substance abuse treatment programs should be geared toward women of childbearing age with alcohol use disorders to prevent FASD occurrence/reoccurrence. Furthermore, alcohol marketing and promotion targeting female adolescents and women of childbearing age should be banned or strictly regulated by governments. Alcohol producers, distributors, and sellers should voluntarily discontinue such marketing, thereby potentially helping to reduce alcohol-related harm in children.

\section{Conflict of interests: None declared.}

Disclaimer. Authors hold sole responsibility for the views expressed in the manuscript, which may not necessarily reflect the opinion or policy of the RPSP/ PAJPH and/or PAHO. 


\section{REFERENCES}

1. World Health Organization. Global Status Report on Alcohol and Health, 2014. Geneva: WHO; 2014. Available from: http: / / apps.who.int/iris / bitstre am/10665/112736/1/9789240692763_eng. pdf?ua $=1$ Accessed on 5 August 2015.

2. Sedgh G, Singh S, Hussain R. Intended and unintended pregnancies worldwide in 2012 and recent trends. Stud Fam Plann. 2014;45(3):301-14.

3. Chudley AE, Conry J, Cook JL, Loock C, Rosales T, LeBlanc N. Fetal alcohol spectrum disorder: Canadian guidelines for diagnosis. CMAJ. 2005;172(5 suppl): S1-21.

4. Little RE. Moderate alcohol use during pregnancy and decreased infant birth weight. Am J Public Health. 1977;67(12): 1154-56.

5. Kesmodel U, Wisborg K, Olsen SF, Henriksen TB, Secher NJ. Moderate alcohol intake during pregnancy and the risk of stillbirth and death in the first year of life. Am J Epidemiol. 2002;155(4):305-12.

6. Kline J, Stein Z, Shrout P, Susser M, Warburton D. Drinking during pregnancy and spontaneous abortion. Lancet. 1980;2 (8187):176-80.

7. Olegard R, Sabel KG, Aronsson M, Sandin B, Johansson PR, Carlsson C, et al. Effects on the child of alcohol abuse during pregnancy. Retrospective and prospective studies. Acta Paediatr Scand Suppl. 1979;275:112-21.

8. Warren KR, Foudin LL. Alcohol-related birth defects-The past, present and future. Alcohol Res Health. 2001;25(3):153-8.

9. Popova L, Lange S, Burd L, Rehm J. The burden and economic impact of Fetal Alcohol Spectrum Disorder in Canada. Toronto, Canada: Centre for Addiction and Mental Health; 2015. Available from: www.camh.ca/en/research/news_and publications/reports_and_books / Documents / Burden $\% 20$ and $\% 20 \mathrm{Eco} \% 20$ Costs $\% 20$ FASD $\% 20 \mathrm{Feb} \% 202015$.pdf Accessed on 1 February 2015

10. Popova S, Lange S, Burd L, Rehm J. Economic burden of Fetal Alcohol Spectrum Disorder in Canada in 2013. Alcohol Alcohol. 2016;51(3):367-75.

11. Grinfeld H, Goldenberg S, Segre CA, Chadi G. Fetal alcohol syndrome in São Paulo, Brazil. Paediatr Perinat Epidemiol. 1999;13(4):496-7.

12. Magri R, Hutson J, Miguez H, Suarez H, Menendez A, Parodi V, et al. Advances in the determination of alcohol and drug consumption during pregnancy: A study of 900 births in Montevideo, Uruguay. Contemp Drug Probl. 2007;34(3):445-76.

13. Mena RM, Nazal LR, Fernández RE, Muñoz OM, Mora MF, Olivo TG, et al. Prevalence of fetal alcohol syndrome at foster homes of the Servicio Nacional de Menores VIII Región, Chile. Rev Med Chil. 1987;115(2):1218-25.

14. Mena RM, Navarrete MP, Avila TP, Bedregal GP, Berrios CX. Ingestión de alcohol en los padres y su relación con el coeficiente intelectual de sus hijos [Alcohol drinking in parents and its relation with the intellectual score of their children]. Rev Med Chil. 1993;121(1):98-105.

15. Miller L, Chan W, Comfort K, Tirella L. Health of children adopted from Guatemala: comparison of orphanage and foster care. Pediatrics. 2005;115:710-18.

16. Liberati A, Altman DG, Tetzlaff J, Mulrow C, Gøtzsche PC, Ioannidis JPA, et al. The PRISMA statement for reporting systematic reviews and meta-analyses of studies that evaluate health care interventions: explanation and elaboration. PLoS Med. 2009;6(7):e1000100.

17. Egger M, Smith GD, Altman DG. Systematic reviews in health care: meta-analysis in context. 2nd ed. London: BMJ Publishing Group; 2008.

18. Wong WCW, Cheung CSK, Hart GJ. Development of a quality assessment tool for systematic reviews of observational studies (QATSO) of HIV prevalence in men having sex with men and associated risk behaviours. Emerg Themes Epidemiol. 2008;5:23.

19. Bush K, Kivlahan DR, McDonell MB, Fihn SD, Bradley KA. The AUDIT alcohol consumption questions (AUDIT-C): an effective brief screening test for problem drinking. Ambulatory Care Quality Improvement Project (ACQUIP). Alcohol Use Disorders Identification Test. Arch Intern Med. 1998;158(16):1789-95.

20. Knight JR, Sherritt L, Shrier LA, Harris SK, Chang G. Validity of the CRAFFT substance abuse screening test among adolescent clinic patients. Arch Pediatr Adolesc Med. 2002;156:607-14.

21. Chasnoff IJ, McGourty RF, Bailey GW, Hutchins E, Lightfoot SO, Pawson LL, et al. The $4 \mathrm{P}^{\prime}$ s Plus screen for substance use in pregnancy: clinical application and outcomes. J Perinatol. 2005;25:368-74.

22. Fleiss J. Measuring nominal scale agreement among many raters. Psychological Bull. 1971;76(5):378-82

23. Freeman MF, Tukey JW. Transformations related to the angular and the square root. Ann Math Stat. 1950;21(4):607-11.

24. DerSimonian R, Laird N. Meta-analysis in clinical trials. Control Clin Trials. 1986;7(3):177-88.

25. Higgins JPT, Thompson SG. Quantifying heterogeneity in a meta-analysis. Stat Med. 2002;21(11):1539-58.

26. Egger M, Smith GD, Schneider M, Minder C. Bias in meta-analysis detected by a simple, graphical test. BMJ. 1997;315(7109):629-34.

27. Popova S, Lange S, Probst C, Gmel G, Rehm J. Estimation of national, regional, and global prevalence of alcohol use during pregnancy and fetal alcohol syndrome: a systematic review and meta-analysis. Lancet Glob Health 5(3), e290-e299.

28. Papke LE, Wooldridge JM. Econometric methods for fractional response variables with an application to $401(\mathrm{k})$ plan participation rates. J Appl Econ. 1996;11:619-32.

29. World Bank. World development indicators. Washington DC, USA: World Bank; 2014. Available from: http://data.worldbank.org/data-catalog/world-development-indicators Accessed on 5 August 2015.
30. Almeida MLD, Santana PA, Guimarães AMDN, Gurgel RQ, Vianna EO. Asma e gravidez: repercussões no recém-nascido [Asthma and pregnancy: repercussions for neonates]. J Bras Pneumol. 2010;36(3): 293-300.

31. Buss C, Nunes MA, Camey S, Manzolli P, Soares RM, Drehmer M, et al. Dietary fiber intake of pregnant women attending general practices in southern Brazil - The ECCAGE Study. Public Health Nutr. 2009;12(9):1392-8.

32. Cesar JA, Mendoza-Sassi RA, GonzálezChica DA, Menezes EHM, Brink G, Pohlmann $\mathrm{M}$ et al. Prevalência e fatores associados à percepção de ocorrência de corrimento vaginal patológico entre gestantes [Prevalence of self-reported vaginal discharge and associated factors in pregnant women]. Cad Saude Publica. 2009 25(12):2705-14.

33. da Silva RA, Jansen K, Souza LDD, Moraes IGD, Tomasi E, da Silva GD, et al. Depression during pregnancy in the Brazilian public health care system. Rev Bras Psiquiatr. 2010;32(2):139-44.

34. De Souza LHRF, Dos Santos MC, De Oliveira LCM. Padrão do consumo de álcool em gestantes atendidas em um hospital público universitário e fatores de risco associados [Alcohol use pattern in pregnant women cared for in a public university hospital and associated risk factors]. Rev Bras Ginecol Obstet. 2012;34(7):296-303.

35. Freire K, Padilha PD, Saunders C. Fatores associados ao uso de álcool e cigarro na gestação [Factors associated with alcohol use and smoking in pregnancy]. Rev Bras Ginecol Obstet. 2009;31(7):335-41.

36. Kroeff LR, Mengue SS, Schmidt MI, Duncan BB, Favaretto ALF, Nucci B. Fatores associados ao fumo em gestantes avaliadas em cidades brasileiras [Correlates of smoking in pregnant women in six Brazilian cities]. Rev Saude Publica. 2004 38(2):261-7.

37. Lopes Brito CM, Vieira GO, Costa MDO, de Oliveira NF. Desenvolvimento neuropsicomotor: o teste de Denver na triagem dos atrasos cognitivos e neuromotores de pré-escolares [Neuropsychomotor development: the Denver scale for screening cognitive and neuromotor delays in preschoolers] Cad Saude Publica. 2011;27(7):1403-14.

38. Mello MAG, de Conceição AF, Sousa SMB, Alcântara LC, Marin LJ, Raiol MRD, et al. HTLV-1 in pregnant women from the Southern Bahia Brazil: a neglected condition despite the high prevalence. Virol J. 2014;11:28.

39. Melo EF Jr, Cecatti JG, Pacagnella RC, Leite DFB, Vulcani DE, Makuch MY. The prevalence of perinatal depression and its associated factors in two different settings in Brazil. J Affect Disord. 2012;136(3):1204-8.

40. Moraes CL, Reichenheim ME. Rastreamento de uso de álcool por gestantes de serviços públicos de saúde do Rio de Janeiro [Screening for alcohol use by pregnant women in public health care in Rio de Janeiro, Brazil]. Rev Saude Publica. 2007;41(5):695-703. 
41. Pinheiro SN, Laprega MR, Furtado EF. Morbidade psiquiátrica e uso de álcool e gestantes usuárias do Sistema único de Saúde [Psychiatric morbidity and alcohol use by pregnant women in a public obstetric service]. Rev Saude Publica. 2005;39 (4):593-8.

42. Santos IS, Matijasevich A, Valle NCJ. Mate drinking during pregnancy and risk of preterm and small for gestational age birth. J Nutr. 2005;135(5):1120-3.

43. Silva CS, Ronzani TM, Furtado EF, Aliane PP, Moreira-Almeida A. Relationship between religious practice, alcohol use, and psychiatric disorders among pregnant women. Rev Psiq Clín. 2010;37(4):152-6.

44. Viellas EF, da Gama SGN, de Carvalho ML, Pinto LW. Factors associated with physical aggression in pregnant women and adverse outcomes for the newborn. J Pediatr (Rio J). 2013;89(1):83-90.

45. Vogt M, Sallum AW, Cecatti JG, Morais SS. Factors associated with the prevalence of periodontal disease in low-risk pregnant women. Reprod Health. 2012;9:3.

46. Zentner LEA, Rondó PHC, Duran MC, Oliveira JM. Relationships of blood lead to calcium, iron, and vitamin $\mathrm{C}$ intakes in Brazilian pregnant women. Clin Nutr. 2008;27(1):100-4.

47. Aros S, Mills JL, Torres C, Henriquez C, Fuentes A, Capurro T, et al. Prospective identification of pregnant women drinking four or more standard drinks ( $\geq 48 \mathrm{~g}$ ) of alcohol per day. Subst Use Misuse. 2006; 41(2):183-97.

48. Barría RM, Santander G, Victoriano T. Factors associated with exclusive breastfeeding at 3 months postpartum in Valdivia, Chile. J Hum Lact. 2008;24(4):439-45.

49. Johri M, Morales RE, Boivin JF, Samayoa BE, Hoch JS, Grazioso CF, et al. Increased risk of miscarriage among women experiencing physical or sexual intimate partner violence during pregnancy in Guatemala City, Guatemala: cross-sectional study. BMC Pregnancy Childbirth. 2011;11:49.

50. Castro-Espinoza JM, Zonana-Nacach A, Valles-Medina AM, Rivera-Valenzuela $\mathrm{H}$. Utilización del seguro popular de salud en mujeres embarazadas [Use of the Popular Health Insurance Program by pregnant women]. Gac Med Mex. 2009;145(4):285-8.
51. Doubova SV, Pámanes-González V, Billings DL, Torres-Arreola LD. Violencia de pareja en mujeres embarazadas en la Ciudad de México [Partner violence against pregnant women in Mexico City]. Rev Saude Publica. 2007;41(4): 582-90.

52. Peña J, Matute E. Consumo de alcohol en mujeres embarazadas atendidas en el Hospital Civil de Guadalajara Dr. Juan I. Menchaca, entre 1991 y 1998 [Alcohol consumption in pregnant women treated at the Civic Hospital of Guadalajara Dr. Juan I. Menchaca between 1991 and 1998]. Espiral. 2010;16(47):211-29.

53. Miguez H, Magri R, Suárez M, Suárez H, Jones J, Putti P. Embarazo y alcoholización social [Pregnancy and social drinking]. Acta Psiquiátr Psicol Am Lat. 2010;56(3): 163-7.

54. Ministry of Health Brazil. Gestação de alto risco: manual técnico [High-risk pregnancy: a technical manual]. Brasilia: Ministry of Health; 2010.

55. Ministry of Health Brazil. Atenção ao prénatal de baixo risco [Attention to low-risk prenatal care]. Brasilia: Ministry of Health, Secretary of Health Care, Department of Primary Care; 2012.

56. National Counsel for Narcotics Control from Chile. Mujeres y tratamiento de drogas: sugerencias para el abordaje de mujeres embarazadas con problemas de drogas [Women and drug use treatment: suggestions for addressing pregnant women with substance use problems]. Santiago: National Counsel for Narcotics Control; 2010.

57. Ministry of Health of Chile. Intervenciones breves para reducir el consumo de alcohol de riesgo: Guía técnica para Atención Primaria de Salud [Technical guide for primary health care: Brief interventions to reduce at-risk alcohol consumption]. Santiago: Ministry of Health of Chile; 2011.

58. World Health Organization. Guía de intervención mhGAP para los trastornos mentales, neurológicos y el uso de sustancias en el nivel de atención de la salud no especializada [Intervention guide for mental, neurological and substance use disorders in non-specialized health settings: Mental Health Gap Action
Programme (mhGAP)]. Geneva: WHO; 2010.

59. Consejo Nacional contra las Adicciones de México. Preguntas frecuentes sobre abuso de alcohol y el alcoholismo [Frequently asked questions about alcohol abuse and alcoholism]. Juárez: Consejo Nacional contra las Adicciones: 2008. Available from: www.conadic. salud.gob.mx/pib/faqs_alcohol.html Accessed on 14 April 2016.

60. Food and Agriculture Organization of the United Nations. FAOSTAT [Internet]. Rome: FAO. Available from: http:// faostat3.fao.org/ Accessed 14 April 2016.

61. Pan American Health Organization (PAHO). Regional Status Report on Alcohol and Health in the Americas. Washington, DC: PAHO; 2015.

62. López MB, Filippei VA, Cremonte M. Consumo de alcohol antes y durante la gestación en Argentina: prevalencia y factores de riesgo [Alcohol consumption before and during pregnancy in Argentina: prevalence and risk factors]. Rev Panam Salud Publica. 2015;37(4-5): 211-7.

63. Magri R, Hutson J, Miguez H, Suarez H, Menendez A, Parodi V, et al. Advances in the determination of alcohol and other drug consumption during pregnancy: A study of 900 births in Montevideo, Uruguay. Contemp Drug Probl. 2007;34: 445-76.

64. Webster GM, Teschke K, Janssen PA. Recruitment of health first-trimester pregnant women: lessons from the Chemicals, Health \& Pregnancy study (CHirP). Matern Child Health J. 2012;16(2):430-8.

65. Williams AD, Nkombo $Y$, Nkodia G, Leonardson G, Burd L. Prenatal alcohol exposure in the Republic of the Congo: Prevalence and screening strategies. Birth Defects Res A Clin Mol Teratol. 2013;97(7):489-96.

Manuscript received on 28 April 2016. Revised version accepted for publication on 3 May 2016. 
RESUMEN

\section{Prevalencia real y prevista del consumo de alcohol durante el embarazo en América Latina y el Caribe: revisión bibliográfica sistemática y metanálisis}

Palabras clave
Objetivo. Calcular la prevalencia del consumo de alcohol durante el embarazo en la población general de América Latina y el Caribe desglosada por país y para el año 2012.

Métodos. Se siguieron tres pasos: 1) una búsqueda bibliográfica sistemática y amplia; 2) metanálisis, en los que se supuso un modelo de efectos aleatorios respecto de los países sobre los que se disponía de estudios publicados; y 3) el modelado de regresión (predicción de datos) respecto de los países sobre los que no se disponía de ningún estudio publicado o estos eran demasiado escasos para obtener estimaciones.

Resultados. Sobre la base de los 24 estudios existentes, se calculó la prevalencia combinada del consumo de alcohol durante el embarazo en la población general de Brasil (15,2 \%; intervalo de confianza [IC] del $95 \%$ : 10,4-20,8 \%) y México (1,2 \%; IC del $95 \%$ : 0,0-2,7\%). También se calculó la prevalencia prevista del consumo de alcohol durante el embarazo en la población general de 31 países, cálculo que arrojó datos comprendidos entre 4,8 \% (IC del $95 \%$ : 4,2-5,4 \%) en Cuba y 23,3 \% (IC del 95\%: 20,1-26,5 \%) en Granada.

Conclusiones. Es preciso redoblar los esfuerzos de prevención e intensificar las medidas en los países de América Latina y el Caribe para impedir que las embarazadas consuman alcohol durante el embarazo a fin de reducir las tasas de los trastornos del espectro alcohólico fetal. También se deben realizar más estudios de buena calidad sobre la prevalencia del consumo de alcohol durante el embarazo en América Latina y el Caribe.

Consumo de bebidas alcohólicas; embarazo; atención prenatal; desarrollo fetal; América Latina; Región del Caribe.
RESUMO

\section{Prevalência real e prevista do consumo de álcool na gravidez na América Latina e Caribe: revisão sistemática da literatura e meta-análise}

Objetivo. Estimar a prevalência do consumo de álcool na gravidez na população geral da América Latina e Caribe, por país, em 2012.

Métodos. Três etapas foram realizadas: (i) uma busca sistemática abrangente da literatura científica, (ii) meta-análises a partir de um modelo de efeitos aleatórios para os países com estudos publicados e (iii) modelos de regressão (predição de dados) para os países sem nenhum estudo publicado ou com um número muito pequeno de estudos para obter uma estimativa.

Resultados. Com base em 24 estudos identificados, estimou-se a prevalência conjunta do consumo de álcool na gravidez na população geral no Brasil (15,2\%; intervalo de confiança de 95\% [IC 95\%] 10,4\%-20,8\%) e no México (1,2\%; IC 95\% 0,0\%-2,7\%). A prevalência do consumo de álcool na gravidez na população geral foi prevista em 31 países, variando de 4,8\% (IC 95\% 4,2\%-5,4\%) em Cuba a 23,3\% (IC 95\% 20,1\%-26,5\%) em Granada.

Conclusões. Um grande esforço de prevenção com a adoção de medidas preventivas se faz necessário nos países da América Latina e Caribe para prevenir o uso de álcool entre gestantes durante a gravidez e reduzir os índices de transtornos do espectro alcoólico fetal. Também são necessários outros estudos de alta qualidade da prevalência do consumo de álcool na gravidez na América Latina e no Caribe.

Palavras-chave Consumo de bebidas alcoólicas; gravidez; cuidado pré-natal; desenvolvimento fetal; América Latina; Região do Caribe. 